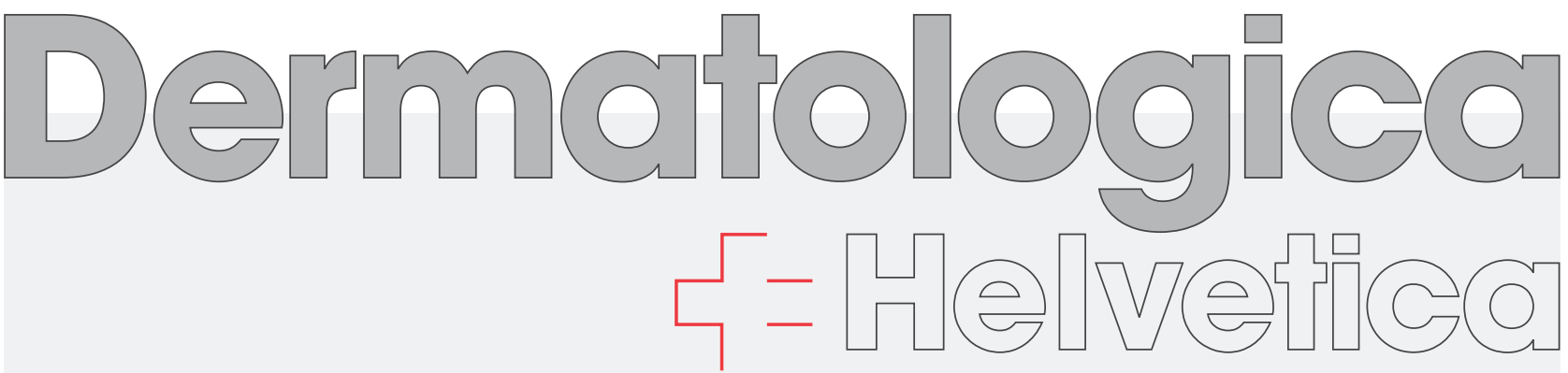

4/23 Nouvelles de la SSDV Neues aus der SGDV

\section{1/17 Annonce} Anzeige

14 Journal-club pour le praticien Journal-Klub für den Praktiker

19 Cas clinique

Klinischer Fall

20 Nouvelles des cliniques Neues aus den Kliniken

31 Billets d'humour et d'humeur Humorvolles und Launiges

32 Nouvelles de l'industrie Neues aus der Industrie

\section{Urticaires chroniques révélant une néoplasie colique}

\section{8e Réunion annuelle de la SSDV 88. Jahresversammlung der SGDV}

\section{Programme préliminaire}

Genève, 21-23 septembre 2006

\section{Vorprogramm}

Genf, 21.-23. September 2006
Avec les compliments des éditions S. Karger, Bâle

Mit den besten Empfehlungen des Verlags S. Karger, Basel
KARGER $\begin{gathered}\text { s. Karger } \\ \text { Basel - Freiburg }\end{gathered}$

Paris $\cdot$ London New York · Bangalore

Bangkok $\cdot$ Singapore

Tokyo $\cdot$ Sydney 